\title{
The Onus of Explanation
}

\section{Sam Popowich ${ }^{1}$}

${ }^{1}$ Library and Museums, University of Alberta, Email: Sam.Popowich@ualberta.ca

To Cite:

Popowich,S. (2021). The Onus of Explanation. [Special Edition]. Pathfinder: A Canadian Journal for Information Science Students and Early Career Professionals, 2(1). https://doi.org/10.29173/pathfinder46

\begin{abstract}
This manuscript contains the text of the key note speech given at the 2021 Forum for Information Professionals.
\end{abstract}

Keywords: Theory, Intersectionality, Critical Theory, Ideology

am speaking to you from Treaty 6 territory - specifically amiskwaciwâskahikan or Edmonton - traditional territory of many First People including Cree, Blackfoot, Nakota Sioux, Saulteaux, Inuit, and Métis. Land acknowledgements sometimes refer to being a "guest" on Indigenous land, but it is important to acknowledge that my being here is no happy accident, but the product of several centuries' of colonial expansion and appropriation, the dialectic of power and violence on the prairies. The fact that I was born in Treaty 1 territory - Winnipeg - is another necessary fact about my life. The fact that it is a fact - and that the treaty framework, the cultural, political, and economic structures of colonialism, and the immemorial societies of First Nations all predate me and, in many ways, determine my life - are important elements that I want to touch on throughout this talk.

I want to talk to you today about the way particular kinds of explanation, particular ways of understanding the world, are vilified and attacked in public discourse. In September of last year, Alberta Premier Jason Kenney criticized the federal 
government's throne speech for not addressing provincial demands. "There was space for every bright shiny object," Kenney said, "every possible political distraction, kooky academic theories like intersectionality found their way into yesterday's throne speech"1. Besides the dismissal of a theoretical tool like intersectionality as "kooky", it is significant that Kenney draws a line between irrelevant distractions - political and academic - and some other position - focused and relevant - that he claims to take. If intersectionality is political and academic, then it implies that Kenney's alternative is somehow not-political (despite Kenney being the head of state in the province of Alberta) and focused on some real-world which the academy is insulated from. Kenney's condemnation of theories like intersectionality is part of a broader trend. At the same time Kenney was responding to the throne speech, in late September 2020, Donald Trump issued an executive order attacking the - quote - "malign ideology" of anti-racist thinking, Critical Race Theory in particular. Critical Race Theory and other anti-racist ways of understanding and explaining the world of racial capitalism were, in Trump's view:

contrary to the fundamental premises underpinning our Republic: that all individuals are created equal and should be allowed an equal opportunity under the law to pursue happiness and prosper based on individual merit. ${ }^{2}$

Like Kenney, Trump has a particular view of society that he wants to present as unchallengeable fact, real, solid, concrete, unquestionable. For both Kenney and Trump what they possess is clear and obvious truth; what they decry is ideology, manipulation, falsification. What I want to talk about here are the power relations expressed by being the one able to draw such distinctions, and the purpose of excluding, condemning, and dismissing alternative explanations from the ones put forward by people in power.

I was born and grew up, as I say, in Winnipeg - also a Métis homeland. Treaty 1 was signed in 1871 by the crown and leaders of the Anishinaabe and Swampy Cree of

\footnotetext{
${ }^{1}$ Woods, Mel. “Jason Kenney on Throne Speech: Intersectionality a 'Kooky Academic Theory'. HuffPost September 24, 2020.

${ }^{2}$ Trump, Donald. E.O. 13950 of Sep 22, 2020; the UK government followed suit a month later, see Trilling, Daniel. "Why is the UK government suddenly targeting 'critical race theory'? Guardian October 23, 2020.
} 
what is currently Southern Manitoba. A year earlier, an act of parliament had created the province in an attempt to decrease tensions between settlers and Métis at the end of the Red River Resistance. Would it be possible to recite this list of names, dates, and descriptions without trying to work out how they are connected? How the various kinds of relationships - between people, between people and the land, between people and institutions like the crown or parliament - formed a context into which my parents' families settled? The different and interlocking histories of Ukraine in the last phase of the Russian Empire, of white-collar workers in post-war Wales, of the settlement of the prairie based on displacement and oppression of Indigenous peoples, of the rise of Winnipeg as "The Chicago of the North" - all these provide another rich and complex context into which I was born and which I have a responsibility to try to comprehend. I don't think it would be possible to try to understand how all those processes interlock to form a material and cultural matrix which produced me without some kind of framework, some sense of how these kinds of histories relate to each other, change, and develop over time. In very real ways these matrices and frameworks help to explain who I am and how I come to know the world.

I'm going to get a bit ahead of myself to say that, at its simplest, all theory is just this: a way of explaining, making sense of the complex material of our lives as it relates to other people's lives, living and dead. But there are many people who would say that on the contrary it is possible to simply "know" these facts, these names, and dates, and institutions - and that such knowledge doesn't require any kind of framework to meet the facts halfway in order to produce real understanding. We'll get back to this idea that theory is somehow optional - in a minute. For now, I want to tell you a little bit about how and why I came to thinking about theory, because there's another view of theory which is similar to the one that claims theory is unnecessary. This other position argues that theory is, well, theoretical, by which is meant something like a fantasy, an illusion, or a flight of imagination - it's not real, has no connection to what is thought of as the real world. But there is no clear distinction between the real world and theory, because that would suggest that people could live their lives without thinking about them and at least trying to understand them. And I don't think this is possible; an unconscious, intuitive call to make communicable connections, to make the vast data of 
experience not just coherent but verbal, is one of the things that distinguishes us from animals.

I was born specifically in the North End of Winnipeg, which has long been a byword of left-wing radicalism. Many of the leaders of the Winnipeg General Strike in 1919 were from the North End. In the racialized class system of early prairie capitalism, the North End was the zone of poor immigrants mostly from Central and Eastern Europe, and Ashkenazy Jews were some of the most active members in the various left-wing organizations, as another North Ender, Leo Panitch - one of Canada's major socialist intellectuals who died in December - often spoke about ${ }^{3}$. Ukrainians too Ukrainians from the Russian Empire who were not, as later Ukrainian immigrants tended to be, anti-communist - were heavily involved in radical working-class institutions, like the People's Co-Op, which lasted from 1928 until the early $1990 \mathrm{~s}^{4}$. Across the railyards from the North End was downtown, and south of downtown was the preserve of the Anglo-Scottish, protestant settler elite. I was born nearly 60 years after the strike, 106 years after the signing of Treaty 1, and yet the same class, ethnic, racial, and religious divisions remained in force. The major class line in Winnipeg was and remains the railyards just North of Downtown. As new waves of immigration arrived, they often occupied downtown itself while the North End came to include more and more people moving into the city from the Southern Manitoba First Nations. The complexion of the North End has changed significantly since I lived there, but this has only served to underline the complexity of ethnic, cultural, and class relationships in the city. This complexity needs to be understood, if only to the extent that it needs to be navigated by those who grow up in it. As I grew up, my social world expanded to include the middle-class south end of the city and I was introduced to class conflict; I went to university, where after the end of the Cold War, liberal thinking appeared triumphant. At eighteen I started working for AT\&T doing internet technical support, which introduced me to the alienation of wage labour. This experience led me to Marxism as a way to understand why this "good job" was so soul-destroying. All of these dynamics had to be

\footnotetext{
${ }^{3}$ Panitch, Leo. 2018. “The Radical Ferment of Winnipeg's Jewish Socialist Politics”. Reality Asserts Itself, March 4, 2018.

${ }^{4}$ Mochoruk, Jim and Kardash, Nancy. The People's Co-Op: The Life and Times of a North End Institution (Halifax: Fernwood Publishing. 2000).
} 
navigated, and this navigation has very real consequences for who one is and how one exists in the world. Power - which lies behind the relationships I'm talking about - is quick to discipline those who step out of line.

What I am trying to get at is this: that there is no clear division between theory and practice. Theory grows out of attempts to make sense of our lives, especially as aspects of them are permitted or forbidden, encouraged or constrained, by people and things outside of ourselves. Almost universally, Marxism, feminism, Indigenous activism, Critical Race Theory, Queer Theory, and many more take seriously the fact that individuals can only be understood as aspects of larger social structures, and for this they are attacked as "ideological" because they reject the common-sense truths of capitalist society, such as individualism. And such theories are ideological. But they are ideologies knowingly and consciously adopted. There is no non-ideological perspective on things, and those who rail hardest against ideology are always simply subject to an ideology they will not or cannot admit: an ideology which presents itself as the commonsense self-evident truth about the world is a mystification and a lie.

In his 1975 book Social Justice and the City, Marxist geologist David Harvey succinctly describes these two kinds of ideology. There is on the one hand, he says, "the unaware expression of the underlying ideas and beliefs which attach to a particular social situation", and on the other hand, there is "the aware and critical exposition of ideas in their social context which is frequently called ideology in the west" ${ }^{\prime 5}$. This dual definition is helpful, I think, because it allows us to reclaim, if we like, the idea of ideology from the debased and oversimplified definition used by politicians. For politicians, ideology is anything that departs from the common-sense, realistic, liberal norm, the perspective - they argue - of the world as it is, without theory. By contrast, we might equate ideology in Harvey's second sense with critical theory itself. By understanding ideology in this way, not only do we reclaim the "critical exposition of ideas in their social context" for feminism, Critical Race Theory, Queer Theory, Marxism, anarchism, etc, but we are able to understand that anytime someone claims that their position is non-ideological, they are themselves under the sway of ideology in the first sense, something they do not acknowledge and are perhaps even unconscious

\footnotetext{
${ }^{5}$ Harvey, David. Social Justice and the City (Athens, GA: University of Georgia Press, 2009): 18. 
of. If the role of critical theory is to emancipate through explanation, the role of these unconscious ideologies is to support, maintain, and reproduce the ideas and values that make racial, colonial, patriarchal capitalism possible. One added benefit of the second way of understanding ideology is that we can understand how our own ideologies are the products of our own histories, our own social contexts. Feminism is an explanation of what it is to live in the context of patriarchal social relations; Critical Race Theory an explanation of what it is to live under white supremacy. And just as those social contexts change over time, our theories and explanations can and do change as well. Only by reclaiming the second way of seeing ideology can we understand how our knowledge of the world changes along with society itself. Any position which thinks of itself as nonideological is unable to do that, unable to historicize and contextualize its own understanding of the world.

This point is crucially important for library and information studies, but it is one excluded from mainstream LIS discourse, relegated to special subfields like critical librarianship. We can understand, now, how and why some ideological positions are openly described as ideological, while others obscure their own ideology by making them appear realistic, natural, or common-sense. Others may have "kooky theories", but we have hard-headed, evidence based, empirical fact. But why should empirical, common-sense, non-theoretical perspectives on the world carry more weight? Put another way, why should ideology be considered a problem, something to be avoided, in some sense, an error? There are many different answers to that question. It is bound up with political, economic, and social changes that go back at least to the Renaissance. One way of approaching the question is to say that the scientific revolution of the 17th century and the "applied science" that enabled the development of capitalism were better at producing the kind of knowledge needed to control natural processes and produce profit. This combination came to be described as "reason" and anything which departed from it was by definition "irrational". The irrational was disordered, inefficient, unprofitable, unscientific, and very likely in thrall to older "superstitious" views of the world. The self-confirming connection between knowledge, control over the natural world, and profit produced a dynamic that is still very much with 
us today. We can think of surveillance or platform capitalism, artificial intelligence, dismissal of Indigenous knowledge, and a host of other examples.

In the post-war period, LIS tended to align itself with this perspective, adopting positivist social-science as its model and benefiting from the role of information and knowledge in the military-industrial complex. Libraries have always been complicit in this form of knowledge colonization. The process of industrial expansion led to great advances and improvements in standards of living for many (though by no means most) of the people on the planet. But it also produced colonial expansion as a way to increase capitalist natural resource extraction, which required that something be done about the people already living on the land who disagreed that it should be used in that way. Theories of racial superiority were developed to make this process easier and more palatable to white sensibilities. It thereby produced white supremacy, as those who saw themselves as masters of the planet (white, male, rational, profitable, scientific, controllers of natural processes and dominators of the natural world) extended this mastery over all others. In doing so they came up with ways to distinguish between themselves and those others, and the lowest common denominator was whiteness. Whiteness was constructed as a way to guarantee and rationalize the processes of enslavement and exploitation the colonizers were already engaged in. One aspect of whiteness, then, is ideological: it serves to support and maintain the status quo, making the existing conditions easier to live with, and as a consequence more difficult, if not impossible, to change.

So what happens to those who, by definition, are irrational or Other, are too ideological, or too emotional, too unintelligent, too unthinking, too unfeeling - criticisms aimed at various times by white, patriarchal capitalists against workers, anarchists, white women, LGBTQ people, and people of colour - what happens to us when we want to raise objections, demand explanations, or put forward explanations of our own? The onus is on us to frame our positions and our arguments in "rational" ways, in ways that use the language of science, of capital, of whiteness, of patriarchy, requiring all the extra work of translation before - maybe - what we are saying can be heard by those with power. 
POPOWICH

I think many of us probably known this quote from Toni Morrison, who said that:

The function, the very serious function of racism is distraction. It keeps you from doing your work. It keeps you explaining, over and over again, your reason for being. Somebody says you have no language and you spend twenty years proving that you do. Somebody says your head isn't shaped properly so you have scientists working on the fact that it is. Somebody says you have no art, so you dredge that up. Somebody says you have no kingdoms, so you dredge that up. None of this is necessary. There will always be one more thing. ${ }^{6}$

The Canadian philosopher Charles Taylor put the same idea more quote "acceptably" because phrased more rationally or scientifically - when he discussed the dominance of individualist social theories over other theories that place more weight on social relationships, structures, and dynamics. Taylor argued that individualistic, "nonideological" theories always have the upper hand. These views "always seem nearer to common sense," he wrote, "more immediately available". He went on to say that "Even though [such theories] don't stand up very well in argument... even though a modicum of explanation is enough to show their inadequacy, nevertheless this explanation is continually necessary"7. He calls this the "onus of explanation", which always falls on the people whose theories, perspectives, and lived experiences are ignored, repressed, or otherwise dismissed from the dominant way of understanding the world. What I find interesting about this is that even this distinction - between what is dominant and what is subaltern, what is acceptable and what is unacceptable, what is rational and what is irrational - all of which are functions not of inherent differences but of power - even this distinction itself is denied by the dominant ideology of patriarchal racial capitalism, which is liberalism itself. One of the main tenets of liberalism is its absolute commitment

\footnotetext{
${ }^{6}$ Morrison, Toni. Portland State University, 1975.

${ }^{7}$ Taylor, Charles. Sources of the Self: The Making of Modern Identity (Cambridge: Cambridge University Press): 196.
} 
to pluralism, to the idea of free expression beyond the reach of power. But this is a myth to let power sleep at night. Liberalism is dominant to such an extent that the political philosopher Raymond Geuss has written that "we seem to have no realistic alternative to it"8.

Liberal pluralism, by claiming to accept all differences ends up flattening out and ignoring difference altogether. We can see this in the rhetoric of "post-racial colour blindness" and "all sides" discourse. This rhetoric and discourse are a key component of Intellectual Freedom. Which we will look at in a moment. There's a psychoanalytical way to look at all this, seeing the dominant ideologies as repressing the unacceptable aspects of colonialism, of racism, of gender and sexual oppression. And there's some truth to that, but there are many other ways to understand how ideology works. But in a way, how this process functions is less important than that it functions. The onus of explanation - the insistence on different views, different knowledges (for example, Indigenous ways of knowing), different lived experiences - are ignored unless they are forced into the homogenous form of scientific language, civil discussion, rational or logical argument, and the list goes on. The onus of explanation is an onus of dismissal, an onus of erasure. So, to return to Jason Kenney's "kooky academic theories like intersectionality", I want to look at one of that theory's key texts. While the term "intersectionality" may have been coined by Kimberlé Crenshaw in $1989^{9}$, the concept came out the work of Black feminist groups like the Combahee River Collective, whose statement in 1977 introduced identity politics and the idea of interlocking systems of oppression into social justice work ${ }^{10}$.

Similarly, in her essay "The Master's Tools Will Never Dismantle the Master's House", Audre Lorde - who was a librarian - challenged the exclusion of difference from the (white, liberal) women's movement and the liberal principle of tolerance that underpinned it. Lorde wrote that:

\footnotetext{
${ }^{8}$ Geuss, Raymond. Outside Ethics (Princeton, NJ: Princeton University Press, 2009): 11.

${ }^{9}$ Crenshawe, Kimberlé. "Demarginalizing the Intersection of Race and Sex: A Black Feminist Critique of Antidiscrimination Doctrine, Feminist Theory and Antiracist Politics." University of Chicago Legal Forum 1989, Issue 1, Article 8: 139-167.

${ }^{10}$ Taylor, Keeanga-Yamahtta. How We Get Free: Black Feminism and the Combahee River Collective (Chicago: Harmarket, 2017).
} 
advocating the mere tolerance of difference between women is the grossest reformism. It is a total denial of the creative function of difference in our lives. Difference must not merely be tolerated, but seen as a fund of necessary polarities between which our creativity can spark like a dialectic. Only then does the necessity for interdependency become unthreatening. Only within that interdependency of different strengths, acknowledged and equal, can the power to seek new ways of being in the world generate, as well as the courage and sustenance to act where there are no charters. ${ }^{11}$

This is such a clear expression of why the onus of explanation is always required: because theories like this challenge the homogeneity, the tolerant reformism, the unwillingness to change the structure of the social world. I want to pick out one phrase from this quote: "Only then does the necessity for interdependency become unthreatening". I have already mentioned pluralism, but one of liberalism's other main commitments which, again, goes back to the earliest days of developing capitalism, is a radical individualism. In the social contract theory of Hobbes, the state of nature is a world of individuals engaged in a "war of all against all" and whose lives are, famously, "solitary, poor, nasty, brutish, and short"12. Only a strong monarch can hold the power to weld these individuals into a society and keep them from killing each other. However, we know that such a state of nature has never existed: human beings have only ever known the interdependency of social relations. Hobbes' theory is an illustration, not of individuals in an ancient state of nature, but of the new individualism made possible, and indeed required, by capitalist profitability. The interdependency of social relations is therefore framed as something which infringes on individual liberty, and therefore something to be feared, rather than what makes individuality possible at all. We will

\footnotetext{
${ }^{11}$ Lorde, Audre. “The Master's Tools will never Dismantle the Master's House”. In Sister Outsider, 110-113 (Freedom, CA: Crossing Press, 1984): 111.

12 "Whatsoever therefore is consequent to a time of war, where every man is enemy to every man, the same is consequent to the time wherein men live without other security than what their own strength and their own invention shall furnish them withal. In such condition there is no place for industry, because the fruit thereof is uncertain, and consequently no culture of the earth, no navigation, nor use of the commodities that may be imported by sea, no commodious building, no instruments of moving and removing such things as require much force, no knowledge of the face of the earth, no account of time, no arts, no letters, no society, and which is the worst of all, continual fear and danger of violent death, and the life of man, solitary, poor, nasty, brutal, and short." Hobbes, Thomas.

Leviathan, With Selected Variants from the Latin Edition of 1688 (Indianapolis: Hackett, 1994): 76.
} 
return to this in a moment. Hobbes' theory seems to us now to be quite extreme and disconcerting. A more familiar, more palatable, form of the social contract derives from John Locke.

In Locke's theory, the power of the monarch is replaced by a representative government held accountable to the body of individuals. A system of checks and balances helps to mediate the different opinions, views, and perspectives of the citizens. This raises the question of who is a citizen? Who gets to participate? Locke the architect of liberal democratic theory - was an investor and shareholder in the Royal African Company, which shipped more slaves to the New World than any other institution. Locke also wrote justifications of the doctrine of terra nullius which allowed the British crown to take over Indigenous lands in North America as if they were vacant. It is obvious that Locke's concept of citizenship, of participation, does not apply to everyone. In fact, the individuals Locke has in mind are, unsurprisingly, just like him: white, male, property-owning, involved in capitalist enterprise. In a word, bourgeois.

Locke's political theory was intended for others like him, and so the "tolerance of difference" only needed to extend to trivial things like whether a particular (white, male, property-owning) royal should be excluded from the line of succession. The principle of tolerance was, therefore, baked in to liberal political and social theory which, since that theory is "common-sense", "realistic", and "non-ideological", is in fact inadequate to dealing with a world where women, queer people, people of colour, people of other cultures and ethnicities can't simply be ignored, oppressed, or assimilated, but have to be taken seriously. The interdependency of the contemporary world, as Audre Lorde identified, strikes fear into the hearts of those who benefit from the racist, sexist, oppressive structures of settler-colonial, patriarchal capitalism. To be born into these matrices means to inherit their ideologies, their perspectives, their cultures as normal and natural. They are internalized within us before we are even born. And so the onus of explanation is an attempt to displace the incumbent, to convince ourselves and others that there are better, more fitting, more just ways of understanding, knowing, and changing the world. Changing ideologies is hard work. Critical theory is hard work. The onus of explanation leads to exhaustion, as Toni Morrison suggested in the earlier quote. 
But again, critical theory can help us understand how and why this is the case. And understanding is a core component of transformation. In one of Marx's most famous aphorisms, the eleventh thesis on Feuerbach of 1846, he writes that "philosophers have only interpreted the world in various ways; the point is to change $\mathrm{it}^{\prime \prime}{ }^{13}$. This aphorism is often, and rightly, interpreted to mean that knowledge, thought, wisdom, philosophy. have to be harnessed to social and political improvement. But there is another way to understand it, which is that theory and practice are never separate, distinct activities. Our lived experience, our reactions to the world we inherit, influence when and how we encounter alternative ways of understanding the world, and those new explanations, new truths, new knowledges, cannot help but materially influence the world in turn.

This has grave implications for library and information studies. For example, we all know this graph:

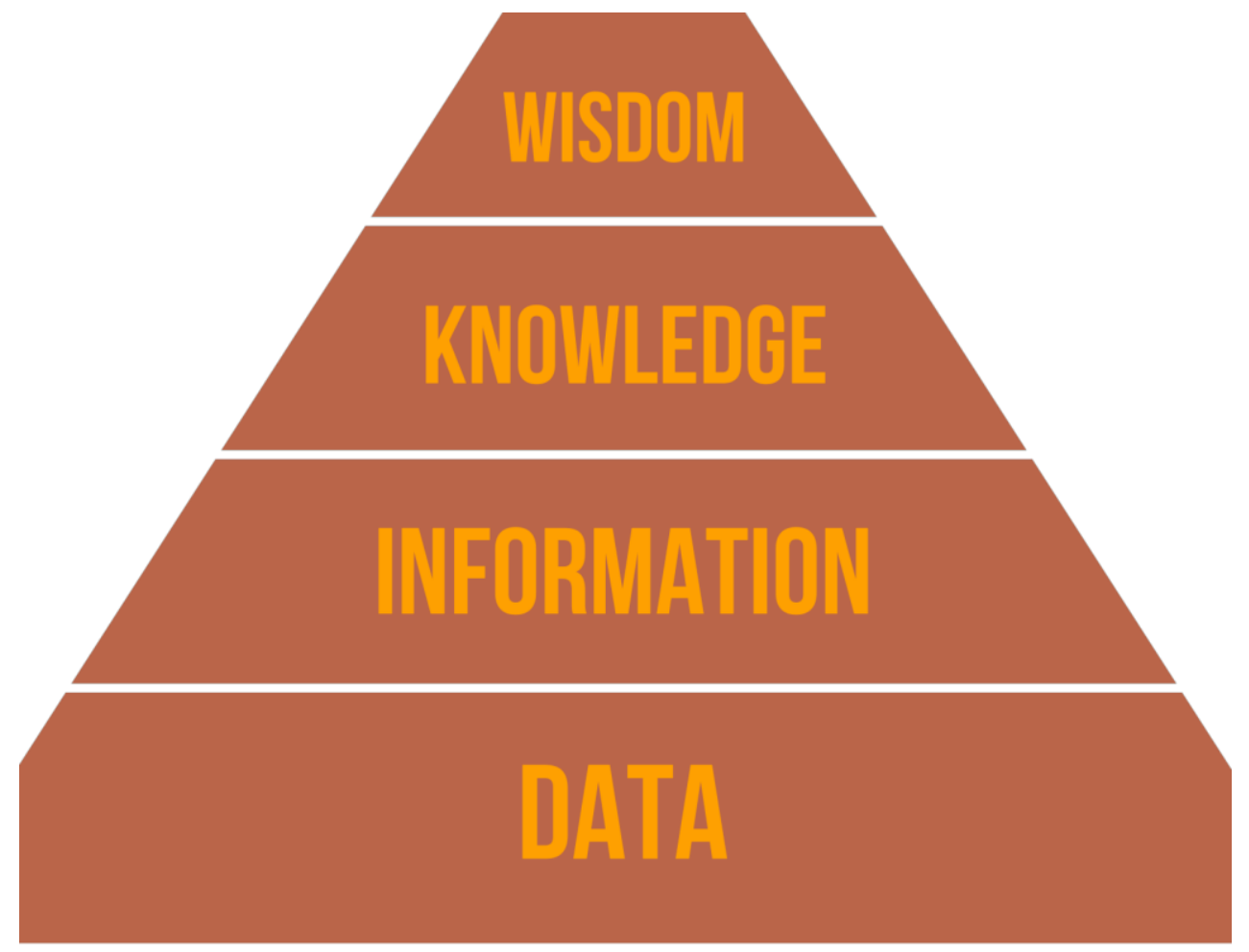

\footnotetext{
${ }^{13}$ Marx, Karl. “Theses on Feuerbach.” In Karl Marx and Frederick Engels, The German Ideology, 615-617 (Moscow: Progress Publishers, 1976): 617.
} 
Sometimes the DIKW model is presented as a directional chain, sometimes as a hierarchy, as it is here. In both cases, however, data is presented as foundational, as raw, uninterpreted, natural facts about the world. This is a positivist epistemological model, intimately connected with bourgeois, liberal ways of thinking and knowing. One thing that critical theories often have in common is the idea that, because we are born into a pre-existing social, cultural, and political world, "facts" are always already preconstructed for us, pre-interpreted. The knowledge of the world that we inherit swings back around to the beginning of the chain or the bottom of the pyramid. The DIKW model would be better presented as a loop or circle; what would the consequences for LIS be then? Nietzsche, in an attack on the kind of positivism represented by the DIKW model, wrote:

Against positivism, which halts at phenomena - "there are only facts" - I would say: No, facts is precisely what there is not, only interpretations. We cannot establish any fact "in itself": perhaps it is folly to want to do such a thing. ${ }^{14}$

In the same section, Nietzsche pushes back against the claim that what he offers instead is the "kooky theory" of pure subjectivism, the impossibility of any and all claims to truth. He insists that there is truth, but truth is never simply given, natural, noninterpreted - we would say now that truth is socially constructed. Truth is perspectival we come to it from and with our lived experience. It is political, economic, inextricable from power. So when someone like Jason Kenney complains that "kooky academic theories like intersectionality" have become part of public discourse, he is holding on to a positivist insistence on facts - normal, natural, immediately available - as part of his political agenda. He isn't wrong that Critical Race Theory, intersectionality, Queer Theory, and Marxism are ideological in the sense that they too have political agendas. But critical theory embraces its political agenda, precisely because its point is not to simply interpret the world, but to change it, to make it better. It doesn't get more political than that. The denial of ideology, the insistence on natural, realistic, common sense facts, is put forward as neutral, non-political, technical, objective, unbiased. And this

\footnotetext{
${ }^{14}$ Nietzsche, Friedrich. The Will to Power (New York: Vintage Books, 1968): 267. 
position is deeply integrated with liberal political philosophy, which sees its role as facilitating the technical control of natural and human resources for the expansion of profit, and in all other senses getting out of people's (some people's) ability to accumulate wealth. This is the perspective of Trump's executive order, which sees the role of the state as ensuring but getting out of the way of individuals' pursuit of happiness and their own idea of the good life. Similarly, it is the dominant conception of Intellectual Freedom in librarianship.

A lot has been written about Intellectual Freedom both from a historical and a philosophical perspective. Toni Samek's Intellectual Freedom and Social Responsibility in American Librarianship ${ }^{15}$ is vital to understanding the larger social debates around the development of Social Responsibility in the 1960s; the Library Juice Press Handbook on Intellectual Freedom ${ }^{16}$ does a good job laying out the accepted philosophical framework of IF. But generally speaking, the question that remains unanswered for IF is what kind of freedom we are talking about. Indeed, this question is almost completely unasked, because it is taken for granted. It is the freedom of isolated individuals free from social conditioning and obligations. As a result, the kind of freedom meant by Intellectual Freedom is, like all other aspects of liberal political thought, considered to be natural, normal, realistic, common-sense, and obvious. The onus of explanation is on critical theory to show how such a conception of freedom is none of those things. It is, instead, a construction designed to shore up and support a particular form of social power.

For example: Donald Trump's executive order referred to "equal opportunity". Equal opportunity is one of the two principles of justice formulated by John Rawls in his 1971 book $A$ Theory of Justice ${ }^{17}$. Rawls' book fundamentally changed political theory by giving liberalism a new foundation during the transition to neoliberalism in the 1970s. But Rawls' principle of equal opportunity is itself based on Isaiah Berlin's concept of

\footnotetext{
${ }^{15}$ Samek, Toni. Intellectual Freedom and Social Responsibility in American Librarianship, 1967-1974 (Jefferson, NC: McFarland, 2001).

${ }^{16}$ Alfino, Mark and Koltutsky, Laura (Eds.) The Library Juice Press Handbook of Intellectual Freedom: Concepts, Cases, and Theories (Sacramento: Library Juice Press, 2014).

${ }^{17}$ Rawls, John. A Theory of Justice, Revised Edition (Cambridge, Mass: Belknap Press, 1999).
} 
negative liberty ${ }^{18}$. Another of Rawls' principles - the principle of difference - maps onto Berlin's concept of "positive liberty". For Berlin, negative liberty is marked by the absence of constraint. People are free insofar as they are not prevented from doing what they want (Berlin ignores the question of how people come to want particular things in the first place). The role of the liberal state and society is to maximize "negative liberty" by removing constraints and obstacles. Negative liberty recognizes that people can have different conceptions of what the good is and how to follow it, and it is not the place of the state or society to try to foster or force adherence to any of those conceptions of the good. That would be what Berlin calls "positive liberty" and it leads, in his view, to the paradoxical position of "people being forced to be free", that is totalitarianism.

Needless to say, Berlin thinks negative liberty is just and proper, and rejects positive liberty as not really liberty at all. Rawls was in many ways responding to Berlin by trying to balance negative and positive liberty in a single theory. This was made necessary because of the explosion of demands for positive conceptions of the good in the late 1960s, such as the Civil Rights Movement, Second Wave Feminism, the Gay Rights Movement, and the Anti-Vietnam War Movement. These were also the demands that led to the reorientation of Intellectual Freedom and Social Responsibility that Samek discusses. Rawls took these demands seriously - he was a supporter of students' rights to protest the Vietnam War and engage in civil disobedience - but he was bound by the liberal preference for negative liberty. Rawls developed his principles of justice as a way to integrate these two conceptions without leading to totalitarianism. The principle of equality of opportunity is primary in Rawls' system - it claims that every individual must have a merit based equal opportunity to succeed in a liberal society. The difference principle argues that a departure from strict equality is legitimate if it improves the lot of the worst off.

In the US, the constitution emphasizes the principle of equality while in Canada the charter of rights emphasizes the difference principle. It is from this distinction that, for example, differences between American and Canadian legal thought around

\footnotetext{
${ }^{18}$ Berlin, Isaiah. “Two Concepts of Liberty.” In Liberty: Incorporating 'Four Essays on Liberty', 166-218 (Oxford: Oxford University Press, 2002).
} 
freedom of speech/expression arises. But pride of place in Rawls - as in all subsequent liberal theories - rests on negative liberty. The thing about negative liberty, though, is that it assumes that there is a non-constructed world out there in which individuals can act freely, a real world of concrete facts that individuals can dominate and transform, as long as the state and the unrealistic members of society with their unrealistic academic theories of social good would just get out of the way. Funnily enough, this concrete real world of facts and control looks, for Berlin and Rawls, just like the existing world of resource extraction, representative government, private property, contract, and exchange. Negative liberty means small-government neoliberalism, getting out of the way of property development, ecological exploitation, attacks on labour, and dismissing questions of structural oppression as ideological and academic by insisting on the (spurious) equality of every individual in society.

The rejection of kooky academic theories, of Marxism, feminism, queer theory, disability theory, Critical Race Theory, is all part of a political project to maintain the legitimacy of patriarchal, cisheteronormaitve, ableist, racial capitalism. The legal conception of individual free speech or free expression is part of this project as well. As a consequence, it follows that Intellectual Freedom as a library value must also be understood in this sense. It is bound by the principle of equality of opportunity and the concept negative liberty. It plays a role in upholding capitalist social, economic, and political relations. And the onus of explanation rests on those of us who see alternative ways of understanding freedom itself.

But let's return for a moment to the issue of facts. Facts may be perspectival, but they are still facts. They are necessary. We can't do anything about them. The fact that I was born where I was, when I was, is necessary for me. The fact that I learned English as a first language means that the culture, books, commercials, pop songs, movies, TV shows, political debates, schooling, etc, were all done from a single cultural and political perspective. I can't change these facts. Wittgenstein once wrote "In the world everything is as it is and happens as it does happen" ${ }^{\prime 1}$. Any conception of freedom must engage seriously with this question of historical necessity.

\footnotetext{
19 " 6.41 The sense of the world must lie outside the world. In the world everything is as it is, and everything happens
} as it does happen: in it no value exists - and if it did exist, it would have no value. If there is any value that does 
Earlier, when I spoke about the fear of interdependency, the need to keep things and people and concepts separated and isolated, it occurred to me that what I was really getting at was the standard logical way of thinking about the world. The logical principle of identity states that a thing is identical to itself: an apple is an apple. The logical principle of contradiction states that a thing cannot be something and not be something at the same time: an apple can't be both red and not-red. The logical principle of the excluded middle states that given two contradictory statements, one must be true and the other false: if "the apple is red" is true, then "the apple is not-red" must be false. These logical "laws" are all based on the idea that things and concepts can easily be separated and isolated. Every fact, in this view, can be investigated and comprehended in isolation from all others. Every individual is isolated and selfdetermining. And we can see this in the DIKW model: each element is its own isolated thing: data is not information, information is not knowledge. Furthermore, just as an apple is always an apple under the traditional laws of logic - it is never a seed and never a leftover core - so the DIKW model is static and eternal, unchanging. Thinking that this can be so is one of the ways traditional logic is pressed into service to support the status quo as logical, natural, true, real, and unable to be changed.

As an individual, based on this logic, I have nothing to do with either the world I grew up in, the languages, laws, customs, and structures of power of that world, or the other people amongst whom I live. I am an isolated, atomic individual with no history, completely free to determine my path in life. This is the social ontology on which Berlin's negative liberty, and hence Rawls' theory of justice, is based, and it is an illusion. Indeed, it often comes close to being an outright lie, as when Margaret Thatcher claimed that "there is no such thing as society, there are only men and women". But this illusion too goes back to the origins of capitalism, the origins of liberalism, as we saw when we looked at social contract theory with its idea of the state of nature composed of isolated individuals at war with each other. It is a hard notion to challenge. But this is precisely what critical theories and theories of social construction do challenge. Back in

\footnotetext{
have value, it must lie outside the whole sphere of what happens and is the case. For all that happens and is the case is accidental." Wittgenstein, Ludwig. Tractatus Logico-Philosophicus (London, New York: Routledge, 2001): 86. I would disagree with Wittgenstein that this makes the world purely "accidental". Rather, I would side with Spinoza and say that this makes the world "necessary".
} 
POPOWICH

1857 Marx criticized this "age-old" view of isolated individuals, which he considered Robinson Crusoe-style myths. Marx wrote that "an individual outside society... is as much of an absurdity as is the development of language without individuals living together and talking to each other" 20 .

Which brings me back to my own development. Born into an exploitative economic system, a spurious democratic political system, an unjust system of property rights, as well as the entire structure of settler-colonialism, patriarchy, and racism, my life has been determined by those things and by my privileged relationship to some of them. Some of us have the privilege of not having to confront these things right away, others are immediately faced with aspects of the world which need to be changed and which therefore require different ways of understanding and explaining them. Indigenous people do not have the luxury of ignoring race, for example; queer people do not have the luxury of avoiding homophobia. This is where critical theories come in. And this I think is where intersectionality is a useful tool to understand both identity *and* difference, individuality and relationality, freedom and necessity.

Métis writer Katherena Vermette's novel The Break ${ }^{21}$ is set where I grew up, in the North End of Winnipeg around Selkirk and McPhillips. She and I are also exactly the same age. But our ways of understanding and explaining the social, economic, and racial makeup of the North End are very different. Each of us sees a part of the whole picture. And individually our freedom is bounded by the necessity of those different experiences. Necessity is not, in this view, the opposite of freedom - as it must be under the three traditional laws of logic - but a component of it. Freedom and necessity are related in complex and constantly changing ways. It follows that, just as the individual of liberalism doesn't really exist - every individual is produced by the social, economic, and cultural relationships into which they are born - so liberalism's individual freedom does not exist either: freedom can only be freedom within our necessary relationships with other people. The Marxist cultural critic Christopher Caudwell sums up this perspective, addressing those progressives who hold to individual conceptions of freedom:

\footnotetext{
${ }^{20}$ Marx, Karl. Grundrisse (London: Pelican Books, 1973): 84.

${ }^{21}$ Vermette, Katherena. The Break (Toronto: House of Anansi, 2016).
} 
Your conception of freedom, because it is rooted in a part of society, is also partial. All consciousness is determined by the society which produces it, but because you are ignorant of this mode of determination, you imagine your consciousness to be free and not determined by your experience and history. This illusion you exhibit so proudly is the badge of your [bondage] to yesterday, for if you could see those causes which determine your thought, you would be like us, on the road to freedom. The recognition of necessity in society is the only passage to social freedom. ${ }^{22}$

What kind of Intellectual Freedom would be possible if we understood freedom itself in this way? How could we change the capitalist, settler-colonial world if we weren't constantly bearing the weight of the onus of explanation? If we were to recognize that anything presented as natural, common-sense, realistic, neutral, or unmarked is not as liberal theory and Jason Kenney would have it - uncommitted to any particular conception of the good, but simply pretending that the goods to which it owes its allegiance - private property, the market, racism, sexism, inequality - are either selfevident or mistakes, imperfections, solely the fault of a few bad apples.

The idea of structural determinations, of the necessary relations into which we are born, is the kind of interdependency that strikes fear into the hearts of those committed to an individualistic society where solidarity and collective action - society itself, really - is impossible. Intellectual Freedom would become, like all other kinds of freedom - and here I'm thinking specifically of anti-vaccination and anti-mask "freedom" - not an individual phenomenon at all, but a social one. It would require that we get over our liberal aversion to positive liberty and embrace the wellbeing and flourishing of human beings in all their radical difference. Neutrality and negative liberty cannot give us that; only positive liberty with a full acceptance of historical necessity can put us on

\footnotetext{
${ }^{22}$ Caudwell, Christopher. Illusion and Reality: A Study in the Sources of Poetry (London: MacMillan, 1937): 287. The epigraph to the book is a quote from Engels' anti-Duhring: "Freedom is the recognition of necessity". 
POPOWICH

the road to a social and collective freedom in which, as the old book has it, the free development of each is a condition for the free development of all ${ }^{23}$.

${ }^{23}$ Marx, Karl and Engels, Friedrich. The Communist Manifesto (London: Penguin Books, 1967): 105. 


\section{References}

Alfino, Mark and Koltutsky, Laura (Eds.) The Library Juice Press Handbook of Intellectual Freedom: Concepts, Cases, and Theories (Sacramento: Library Juice Press, 2014).

Berlin, Isaiah. "Two Concepts of Liberty." In Liberty: Incorporating 'Four Essays on Liberty', 166-218 (Oxford: Oxford University Press, 2002).

Caudwell, Christopher. Illusion and Reality: A Study in the Sources of Poetry (London: MacMillan, 1937).

Crenshawe, Kimberlé. "Demarginalizing the Intersection of Race and Sex: A Black Feminist Critique of Antidiscrimination Doctrine, Feminist Theory and Antiracist Politics." University of Chicago Legal Forum 1989, Issue 1, Article 8: 139-167.

Geuss, Raymond. Outside Ethics (Princeton, NJ: Princeton University Press, 2009). Harvey, David. Social Justice and the City (Athens, GA: University of Georgia Press, 2009).

Hobbes, Thomas. Leviathan, With Selected Variants from the Latin Edition of 1688 (Indianapolis: Hackett, 1994).

Lorde, Audre. "The Master's Tools will never Dismantle the Master's House". In Sister Outsider, 110-113 (Freedom, CA: Crossing Press, 1984).

Marx, Karl. Grundrisse (London: Pelican Books, 1973).

Marx, Karl. "Theses on Feuerbach." In Karl Marx and Frederick Engels, The German Ideology, 615-617 (Moscow: Progress Publishers, 1976).

Marx, Karl and Engels, Friedrich. The Communist Manifesto (London: Penguin Books, 1967): 105.

Mochoruk, Jim and Kardash, Nancy. The People's Co-Op: The Life and Times of a North End Institution (Halifax: Fernwood Publishing. 2000).

Morrison, Toni. Portland State University, 1975.

Nietzsche, Friedrich. The Will to Power (New York: Vintage Books, 1968.

Panitch, Leo. 2018. "The Radical Ferment of Winnipeg's Jewish Socialist Politics". Reality Asserts Itself, March 4, 2018.

Rawls, John. A Theory of Justice, Revised Edition (Cambridge, Mass: Belknap Press, 1999). 
POPOWICH

Samek, Toni. Intellectual Freedom and Social Responsibility in American Librarianship, 1967-1974 (Jefferson, NC: McFarland, 2001).

Taylor, Charles. Sources of the Self: The Making of Modern Identity (Cambridge: Cambridge University Press).

Taylor, Keeanga-Yamahtta. How We Get Free: Black Feminism and the Combahee River Collective (Chicago: Harmarket, 2017).

Trilling, Daniel. "Why is the UK government suddenly targeting 'critical race theory'? Guardian October 23, 2020.

Trump, Donald. E... 13950 of Sep 22, 2020.

Vermette, Katherena. The Break (Toronto: House of Anansi, 2016).

Wittgenstein, Ludwig. Tractatus Logico-Philosophicus (London, New York: Routledge, 2001).

Woods, Mel. "Jason Kenney on Throne Speech: Intersectionality a 'Kooky Academic Theory'. HuffPost September 24, 2020. 